\title{
Users Perception of the Mobile Usability of a Global Bicycle Sharing Platform
}

\author{
https://doi.org/10.3991/ijim.v13i11.11298 \\ Azham Hussain ${ }^{(凶)}$, Emmanuel O.C. Mkpojiogu, Noor Nabeel, Ahmed Al-Athwari \\ Universiti Utara Malaysia, Sintok, Kedah Malaysia \\ azhamh17@yahoo.com
}

\begin{abstract}
Global bicycle sharing platform offers commuters an accessible, convenient and eco-friendly alternative mode of transport. The study reports on the users' perception about the mobile usability of oBike, a global bicycle sharing platform. Fifteen participants were recruited for the study. The study outcome reveals that most of the participants found that the oBike mobile application needs to be enhanced to improve their satisfaction. Some recommendations were proffered that if implemented will guarantee the improvement of the application.
\end{abstract}

Keywords - Mobile app; perceived usability; usability test evaluation

\section{Introduction}

oBike is a Global Bicycle Sharing Platform that offers commuters an accessible, convenient and eco-friendly alternative mode of transport. It is the first homegrown smart stationless bike-sharing platform available 24/7. It was launched in Singapore in February 2017 and has expanded to 24 countries including Malaysia. Its latest smart Bluetooth technology improves the location accuracy of its bicycles, enabling users to identify the nearest oBike. Users scan the QR code via the oBike application and cycle their way to better fitness. In addition, via oBike application the user can be guided to simply park the oBike at any designated public bike-parking areas.UUM students (15 in number) conducted an onsite usability test using smart phones and the latest version of oBike App. The usability test procedure include: i) introduce the group members and their background. 2) explain the system and what it is used for; ii) give the users the smart phones to execute a list of tasks with emphasis that they are testing the application and not the users; iii) give the user apost-task questionnaire to complete. 5) Collect the questionnaire from users. The test session captured each participant's navigational choices, task completion rates, comments, overall satisfaction ratings, questions and feedback [1-15]. 


\subsection{Methodology}

Fifteen (15) students in the UUM campuswere recruited for the study. The recruitment was done in two places: at the Mall and the Sport Centre. The participants were purposively selected to conduct the test, complete the given tasks and give feedback about their use of the application in the form of questionnaire after completing the required tasks. The instrument used to capture data includes the following: Screen: the participants assessed the screen layout of the app (i.e., the user interface).Terminology and application information: participants were asked about the suitability of the terminologies and information provided in the application. Learning: participants assessed the learning tips shown in the application. Application capabilities: the application performance and capabilities to serve the customers was assessed. General impressions: this was designed to assess the overall user impression about the application. Other reactions, impressions and comments: this section is an open-ended question to give user an opportunity to express their sentiments [16-29].

The five tasks used in the study are as follows:

- Pay now "Top Up”

- Check my wallet

- Search and reserve

- Unlock bike

- Logout.

Task 1:Make a payment "top up" can be done after logging in to the oBike application account. The user must have a bank account to complete this task as shown below in figure 1 .
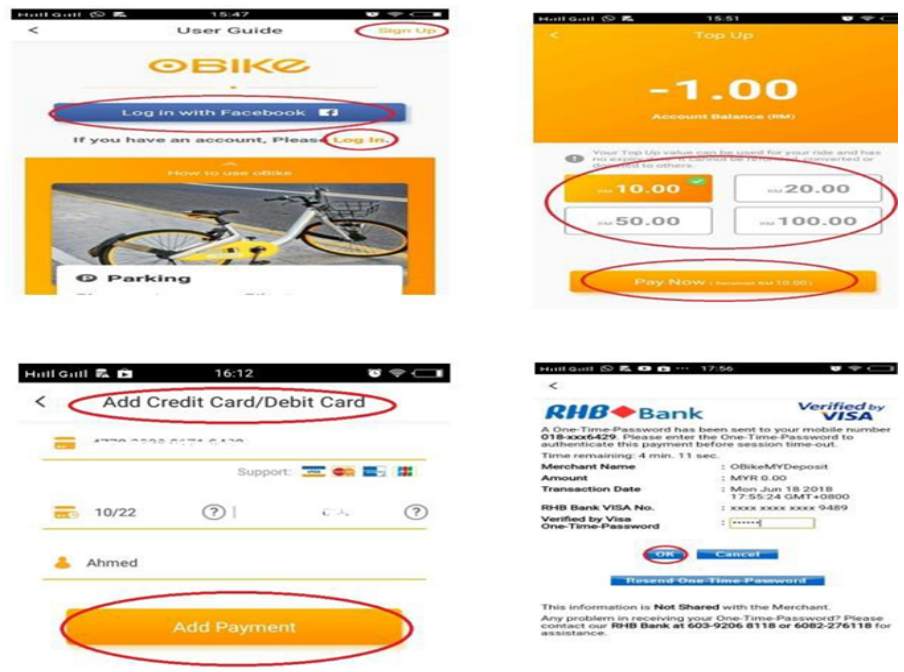

Fig. 1. Task 1: Make payment 
Task 2: Check my wallet can be done straight after starting the application as shown below in figure 2. The steps are: starting an application, click the menu icon, click my wallet.
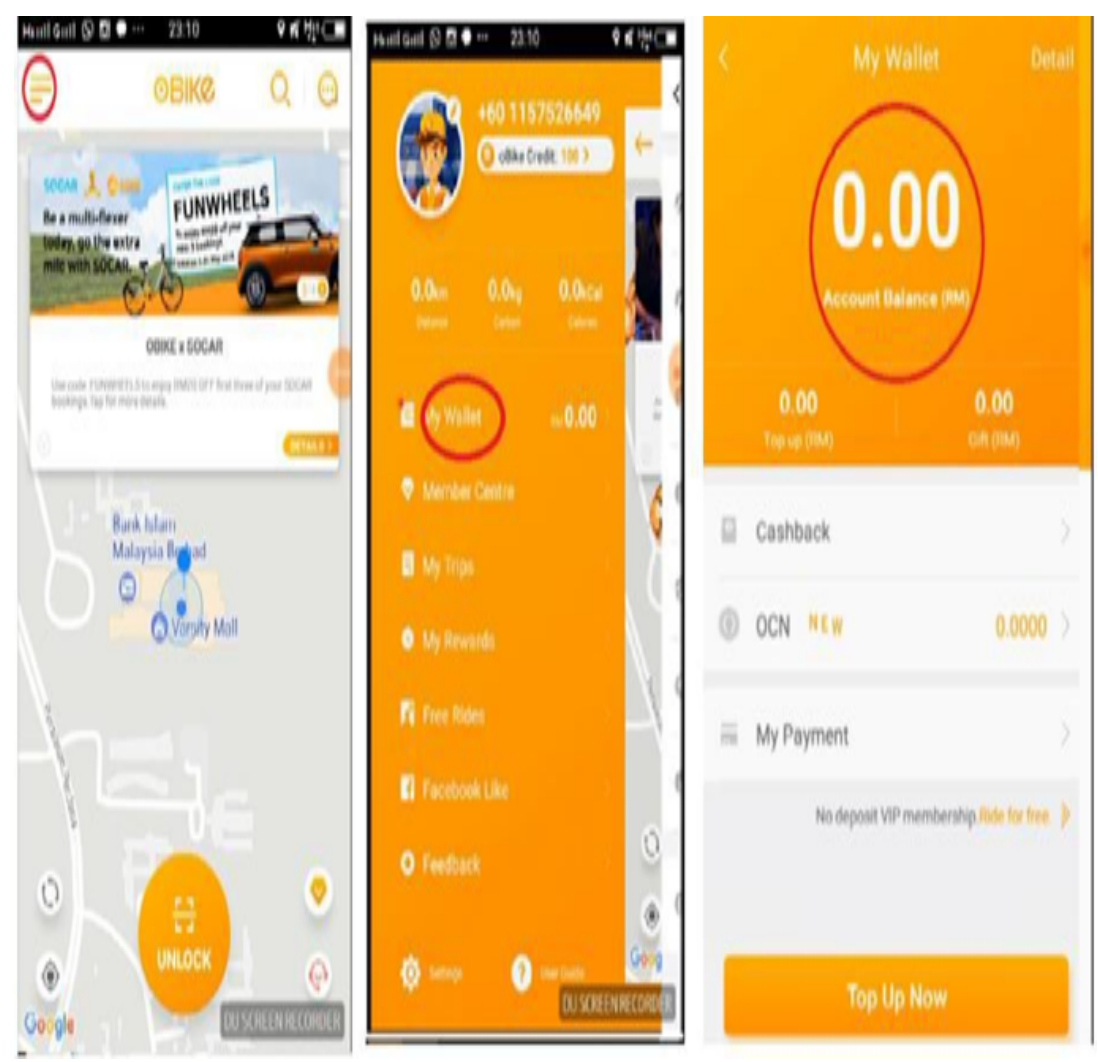

Fig. 2. Task2-chick my wallet

Figure 2: Task 2 - Check my Wallet: Task 3: Search and reserve oBike bike. This task demonstrates that the user can search for the bike around him/her or can search for it in any location that bikes are available to reserve the oBike bike. The steps involved are: search for the required location that user want to reserve, search the required location, select the oBike bike icon, click reserve (figure 3). 


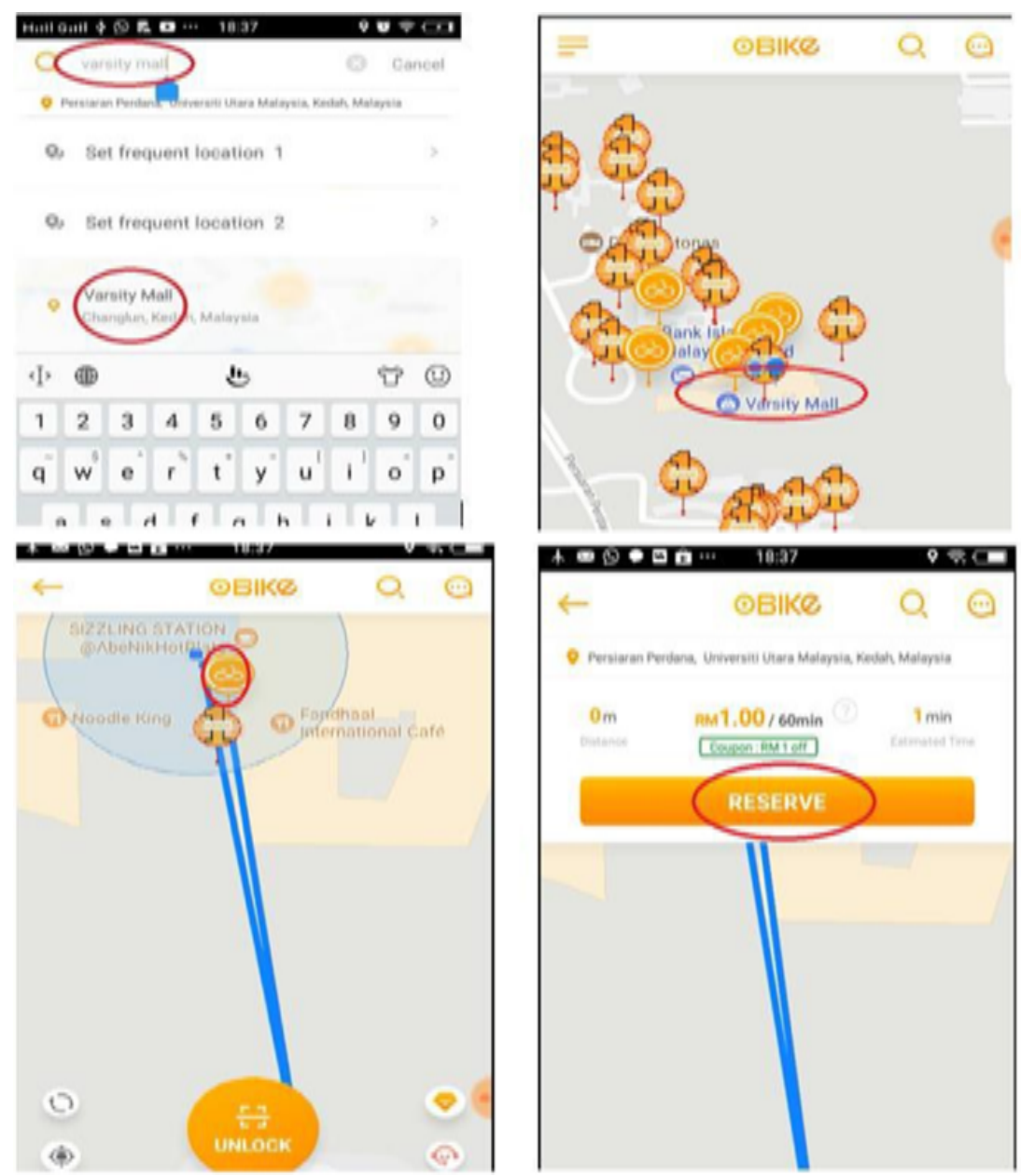

Fig. 3. Task3 - Search and Reserve

In this task most users took long time and faced difficulties in finding the reserved oBike bike. It took a long time following the path that the reserved bike takes even when the bike is close to the user.

Task 4:Unlock locked oBike bike. This task demonstrates that the user can unlock the locked oBike bike by scan $\mathrm{QR}$ or by entering the bike ID number. The steps include: click unlock icon, scan QR or enter the bike ID number (figure 4). 

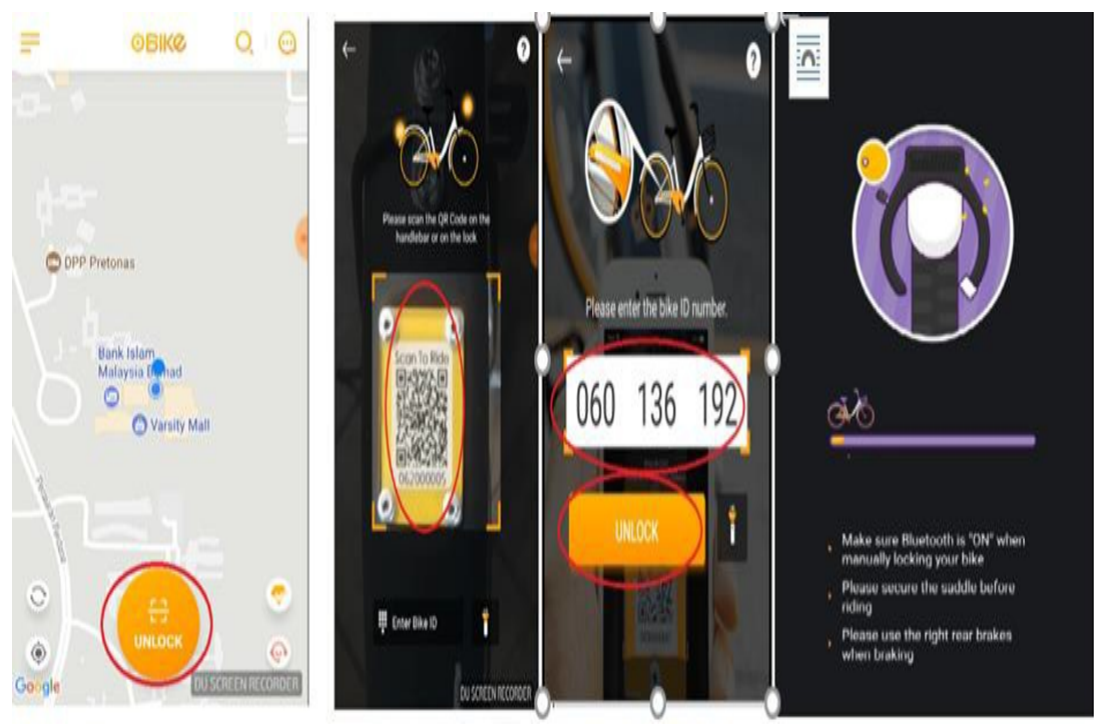

Fig. 4. Task 4 - Unlock locked oBike Bike

Task 5:Log out. In this task, the user logs out from their oBike account.

The steps are: click menu icon, click settings icon, click log out icon, and click ok (figure 5).
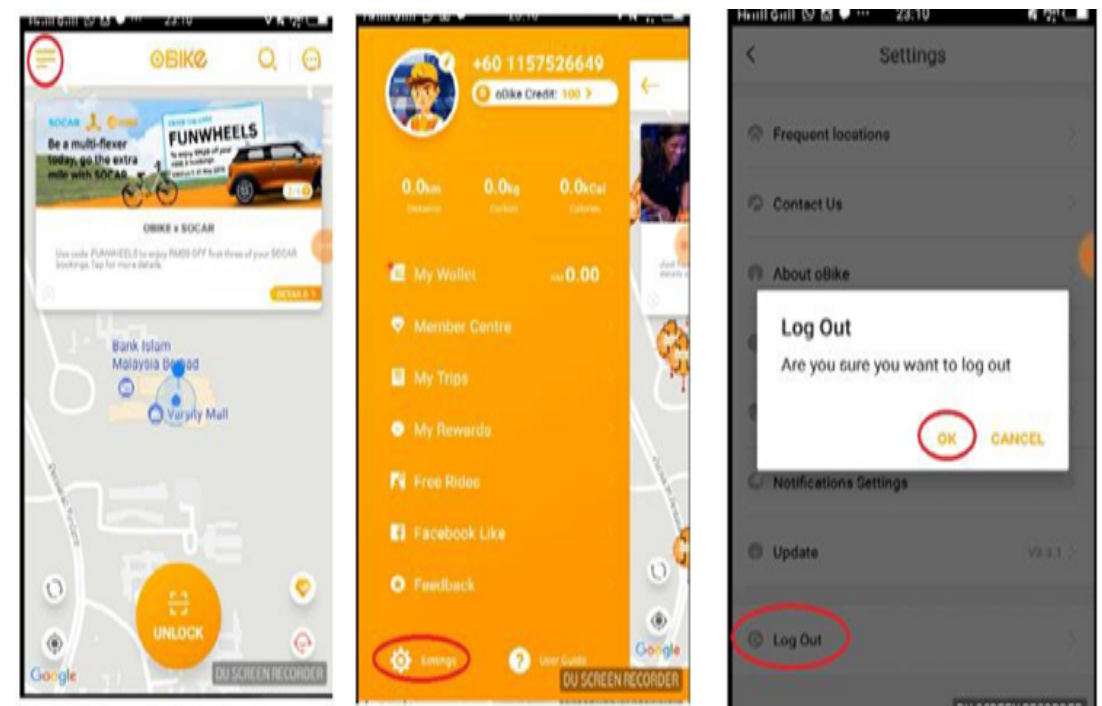

Fig. 5. Task5 - Log out from oBike account

Participants: as afore mentioned, 15 participants were conscripted from among the Universiti Utara Malaysia (UUM) students. The sampling was donepurposively. The 
testing was done in two places at the UUM campus, Sintok: Sport Centre and beside Varsity-Mall between $26 / 04 / 2018$ to $13 / 6 / 2018$. Seventy-three percent (73\%) of the participants were male while $27 \%$ were female. Age wise, $60 \%$ of participants were aged 25 -below, 33\% were aged $26-35$ while $7 \%$ were aged $36-45$. While forty percent (40\%) were expert users, $60 \%$ were novice users.

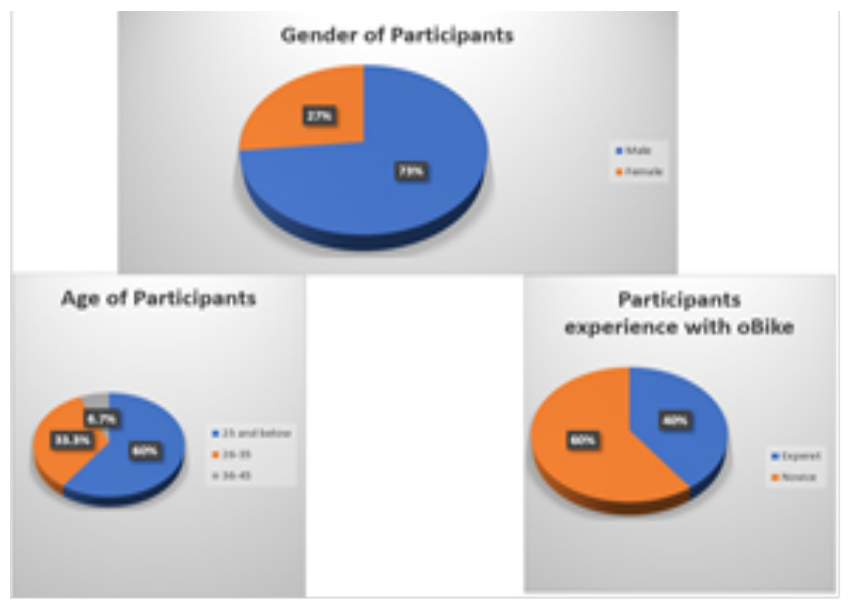

Fig. 6. Participants' Demographics

\section{Results and Discussion}

After the task session was completed, participants rated the app (site)with twentyone overall measures. The result is shown in Table 1 . Of the 21 items, 5 were low performance ratings (below 50\%). Participants rated the items as follows: The menu items were well organized and functions were easy to find $(33.40 \%)$. Uses of terms throughout application are consistent $(46.70 \%)$. Messages (feedback) which appear on screen are NOT confusing (40\%). Error messages are helpful (46.70\%). Tasks always can be performed in a straight- forward manner $(46.70 \%)$. The low ratings indicates that there usability issues that need to be attended to. However, items with high ratings indicate good usability. They are as follows: Characters on the touch screen are easy to read $(80 \%)$. I immediately understand the function of each menu item $(53.30 \%)$. Screen items are easy to select $(60 \%)$. Instructions to the user are clear (53.30\%). Application keeps you informed about what it is doing (66.70\%). Learning to operate the application is easy $(66.70 \%)$. Explorations of features by trial and error are encouraged $(73.30 \%)$. Remembering terms and use of commands is easy $(80 \%)$. Help messages on the screen are clear $(60 \%)$. Application speed is fast enough $(53.40 \%)$. Application sounds tend to be appropriate (60\%). Correcting your mistakes is easy $(66.70 \%)$. The needs of both experienced and inexperienced users are taken into consideration $(60 \%)$. Screens are aesthetically pleasing $(66.70 \%)$. Application is very much impressive (66.70\%).Application is user friendly (60\%) [30-45]. 
In addition, Table 2 stipulates recommended changes that should be made on the interface along with justifications for such recom-mendations and the risks (severity ratings) associated with not effecting the changes.

Table 1. Overall Ratings

\begin{tabular}{|c|l|c|}
\hline S/N & \multicolumn{1}{|c|}{ Measure } & $\%$ \\
\hline 1 & Characters on the touch screen are easy to read. & $80 \%$ \\
\hline 2 & The menu items were well organized and functions were easy to find. & $33.40 \%$ \\
\hline 3 & I immediately understand the function of each menu item. & $53.30 \%$ \\
\hline 4 & Screen items are easy to select. & $60 \%$ \\
\hline 5 & Uses of terms throughout application are consistent. & $46.70 \%$ \\
\hline 6 & Messages (feedback) which appear on screen are NOT confusing. & $40 \%$ \\
\hline 7 & Instructions to the user are clear. & $53.30 \%$ \\
\hline 8 & Application keeps you informed about what it is doing. & $66.70 \%$ \\
\hline 9 & Error messages are helpful. & $46.70 \%$ \\
\hline 10 & Learning to operate the application is easy. & $66.70 \%$ \\
\hline 11 & Explorations of features by trial and error are encouraged. & $73.30 \%$ \\
\hline 12 & Remembering terms and use of commands is easy. & $60 \%$ \\
\hline 13 & Tasks always can be performed in a straight- forward manner. & $46.70 \%$ \\
\hline 14 & Help messages on the screen are clear. & $60 \%$ \\
\hline 15 & Application speed is fast enough. & $53.40 \%$ \\
\hline 16 & Application sounds tend to be appropriate. & $60 \%$ \\
\hline 17 & Correcting your mistakes is easy. & $66.70 \%$ \\
\hline 18 & The needs of both experienced and inexperienced users are taken into consideration. & $60 \%$ \\
\hline 19 & Screens are aesthetically pleasing. & $66.70 \%$ \\
\hline 20 & Application is very much impressive. & $66.70 \%$ \\
\hline 21 & Application is user friendly. & $60 \%$ \\
\hline
\end{tabular}

Table 2. Recommendations

\begin{tabular}{|l|l|c|}
\hline \multicolumn{1}{|c|}{ Change/Update Requirements } & \multicolumn{1}{|c|}{ Justification } & \multicolumn{1}{|c|}{$\begin{array}{c}\text { Risk } \\
\text { (Severity) }\end{array}$} \\
\hline $\begin{array}{l}\text { The icons should be re-fixed (Task 3). The bike and } \\
\text { promotions icons should be clear to the users to let } \\
\text { them distinguish between the icons and to make the } \\
\text { app easily learnable especially for those who are } \\
\text { novices. Sometimes the expert users also face this } \\
\text { problem especially with some versions of the } \\
\text { application. }\end{array}$ & $\begin{array}{l}\text { Took the maximum time to finish. } \\
\text { Took 30\% of time required to finish all } \\
\text { tasks in addition to user comments in } \\
\text { the questionnaire. Task3 required the } \\
\text { highest amount of time to learn. }\end{array}$ & High \\
\hline $\begin{array}{l}\text { Task 5 - Logout: the logout button should be in the } \\
\text { main menu of the application. It should be redesigned. }\end{array}$ & $\begin{array}{l}\text { Many users find it problematic to find } \\
\text { second highest time to learn. } \\
\text { secout function. This took the }\end{array}$ & High \\
\hline $\begin{array}{l}\text { Metric: menu items were well organized and functions } \\
\text { were easy to find. This is the metric that measures } \\
\text { how the functionalities are easy to use. It should be } \\
\text { redesigned so that the functions can be easy to find }\end{array}$ & $\begin{array}{l}\text { Got the lowest percentage } \\
\text { rating(33.4\%).Particularly the finding } \\
\text { of the logout functionality. }\end{array}$ & High \\
\hline $\begin{array}{l}\text { Metric: Uses of terms throughout application are } \\
\text { consistent. The terms throughout an application should } \\
\text { be consistent. }\end{array}$ & $\begin{array}{l}\text { Got low percentage rating of } 46.7 \% . \\
\text { The payment task for instance, has two } \\
\text { terms: pay now and top up. This } \\
\text { confuses users. }\end{array}$ & High \\
\hline $\begin{array}{l}\text { Metric: Messages (feedback) which appear on screen } \\
\text { are NOT confusing. The messages (feedback) which } \\
\text { appear on screen should be clear. }\end{array}$ & \begin{tabular}{l} 
Got low percentage rating of $40 \%$. \\
\hline $\begin{array}{l}\text { Metric: Error messages are helpful. The error } \\
\text { Got low percentage rating of } 46.7 \% .\end{array}$
\end{tabular} & High \\
\hline
\end{tabular}




\begin{tabular}{|l|l|l|}
\hline messages should be helpful for user to learn easily. & & \\
\hline $\begin{array}{l}\text { Metric: Tasks can always be performed in a straight- } \\
\text { forward manner. Tasks should be done in a straight- } \\
\text { forward manner. }\end{array}$ & Got low percentage rating of $46.7 \%$. & High \\
\hline
\end{tabular}

\section{Conclusion}

In this study, 15 participants from UUM were involved in the usability test and results were quite informative. Most of the par-ticipants found that oBike mobile application needs to be enhanced to improve the satisfaction of user needs. Implementing the recommendations guarantees enhancing the application and will ensure a continued user-centered mobile application. The study recommends changes and justifications driven by the participant success rate, behaviours, and comments. Each recommendation includes a severity rating. The following recommendations were suggested to improve the overall ease of use and address the areas where participants experienced problems or found the inter-face/information architecture unclear. Task 3 requires the partici-pants to Search and reserve, Task 5 requires users to logout from oBike account. These two tasks showcased the need for improve-ment of the interface. The response of users to the following measures like" menu items were well organized and functions were easy to find", "uses of terms throughout application are consistent", "uses of terms throughout the application are consistent", "error messages are helpful" and "tasks can always be performed in a straight-forward manner" elicited need for interface enhancement [45-53].

\section{$4 \quad$ References}

[1] Hussain, A, Mkpojiogu, EOC, Yahaya, NB \& Bakar, NZBA (2018), A mobile usability assessment of an m-shopping app. Journal of Advanced Research in Dynamical and Control Systems (JARDCS) 10 (SI), 1212-1217. https://doi.org/10.1063/1.5055455

[2] Gündüz, F \& Pathan, ASK (2013), On the key factors of usability in small-sized mobile touch-screen application. Int. J. Multimed. Ubiquitous Eng, 8(3), 115-138.

[3] Kaikkonen, A, Kekäläinen, A., Cankar, M, Kallio, T \& Kankainen, A (2005), Usability testing of mobile applications: A comparison between laboratory and field testing. Journal of Usability Studies, 1(1), 4-16.

[4] Hussain, A, Mkpojiogu, EOC, Jamalsse, A \& Mohammed, RA (2018), Grab mobile app: a UX assessment on mobile devices. Journal of Advanced Research in Dynamical and Control Systems (JARDCS) 10 (SI), 1233-1238.

[5] Liu, F (2008), Usability Evaluations on Websites. School of Art \&Design, Wuhan University of Technology, Wuhan, Hubei Province, p: 141.

[6] Dumas, JS \& Redish, J (1999), A practical Guide to Usability Testing. Intellect Ltd, UK, US.

[7] Srivasta, J, Cooley, R, Deshpande, M \& Tan, PN (2000), Web Usage Mining: Discovery and Application of Web Usage Pattern from Web Data. Department of Computer Science and Engineering, University of Minnesota. https://doi.org/10.1145/846183.846188 
[8] Mkpojiogu, EOC, Hussain, A \& Hassan, F (2018), A systematic review of usability quality attributes for the evaluation of mobile learning applications for children. ICAST 2018, AIP Conf. Proc. 2016, https://doi.org/10.1063/1.5055494

[9] Icela, L (2017), Usability evaluation focused on user experience of repositories related to energy sustainability : A Literature Mapping.

[10] Nayebi, F, Desharnais, JM \& Abran, A (2012), The state of the art of mobile application usability evaluation, 2012 25th IEEE Can. Conf. Electr. Comput. Eng., 1-4. https://doi.org/ $10.1109 /$ ccece. 2012.6334930

[11] Paz, F \& Pow-Sang, JA (2014), Current Trends in Usability Evaluation Methods: A Systematic Review, 2014 7th Int. Conf. Adv. Softw. Eng. Its Appl., pp: 11-15. https://doi. org/10.1109/asea.2014.10

[12] Hussain, A, Mkpojiogu, EOC \& Suleiman, K (2018), A usability testing of a mobile print shop booking and design application. Journal of Advanced Research in Dynamical and Control Systems (JARDCS) 10 (SI), 1359-1365.

[13] Holzinger, A (2005), Usability engineering methods for software developers. Communications of the ACM, 48(1), 71-74. https://doi.org/10.1145/1039539.1039541

[14] Molich, R, \& Wilson, C (2008), Tips and tricks for avoiding common problems in usability test facilitation. CHI'08 extended abstracts on Human factors in computing systems. ACM, pp: 2379-2382. https://doi.org/10.1145/1358628.1358689

[15] Hussain, A, Mkpojiogu, EOC, Suleiman, K \& Alhussian, H (2018), A heuristic evaluation of a mobile print and design shopping application. Journal of Advanced Research in Dynamical and Control Systems (JARDCS) 10 (SI), 1457-1462. Buchanan, S, \& Salako, A (2009), Evaluating the usability and usefulness of a digital library. Library Review, 58(9), 638-651. https://doi.org/10.1108/00242530910997928

[16] Rubin, J \& Chisnell, D (2008), Handbook of Usability Testing: How to Plan, Design, and Conduct Effective Tests. Canada: John Wiley \& Sons, Inc.

[17] Hussain, A, Mkpojiogu, EOC, Abduljabbar, AM \& Almadhagi, AHG (2018). UUM mobile for students: a usability evaluation on two mobile OS platforms. Journal of Advanced Research in Dynamical and Control Systems (JARDCS) 10 (SI), 1514-1519. https://doi.org/10.1063/1.5055454

[18] Gündüz, F \& Pathan, ASK (2012), Usability improvements for touch-screen mobile flight booking application: A case study. 2012 International Conference on Advanced Computer Science Applications and Technologies (ACSAT), IEEE, pp: 49-54. https://doi.org/10.11 09/acsat.2012.9

[19] Dillon, A (2002), Beyond usability: process, outcome and affect in human-computer interactions. Canadian Journal of Library and Information Science.

[20] Mkpojiogu, EOC \& Hussain, A (2018), Assessing the influence of self-reported requirements importance on the perceived quality of proposed software products. ICAST 2018, AIP Conf. Proc. 2016, 020091, https://doi.org/10.1063/1.5055493

[21] Ahmad, N, Boota, MW \& Masoom, AH (2014), Smart Phone Application Evaluation with Usability Testing Approach, J. Softw. Eng. Appl., 7(12), 1045. https://doi.org/10.4236/js ea.2014.712092

[22] Brown, ME \& Hocutt, DL (2015), Learning to Use, Useful for Learning: A Usability Study of Google Apps for Education, J. Usability Stud., 10 (4), 160-181.

[23] Hussain, A, Mkpojiogu, EOC, Isse, AJ \& Mohammed, RA (2018), Grab mobile application: a usability evaluation. ICAST 2018, AIP Conf. Proc. 2016, 020054, https:// doi.org/10.1063/1.5055456 
[24] ISO 9241-11 (1998), Ergonomic requirements for office work with visual display terminals (vdts)-part 11: Guidance on usability. ISO Standard 9241-11: 1998. International Organization for Standardization. https://doi.org/10.3403/01822507u

[25] Hussain, A, Mkpojiogu, EOC, Yahaya, NB \& Bakar, NZBA (2018), A mobile usability assessment of carousell mobile app. ICAST 2018, AIP Conf. Proc. 2016. 020053, https:// doi.org/10.1063/1.5055455

[26] Bartek, V \& Cheatha, MD (2003), Experience Remote Usability Testing, Part 2: Examine the Benefits and downside of Remote Usability Testing. http://www.mendeley.com/ research/experience-remote-usability-testing-part-2-examine-benefits-downside-remote-us ability-testing/. https://doi.org/10.22215/etd/2003-05659

[27] Hussain, A, Mkpojiogu, EOC, Abduljabbar, AM \& Almadhagi, AHG (2018), A usability evaluation of UUM mobile for students app on IOS and android platforms. ICAST 2018, AIP Conf. Proc. 2016, 020052, https://doi.org/10.1063/1.5055454

[28] Chau, P. Cole, M, Massey, AP, Montoya-Weiss, M \& O'Keefe, RM (2002), Cultural differences in consumer's online behaviors. Commun. ACM, 45(10), 45-50. https://doi. org $/ 10.1145 / 570907.570911$

[29] Hussain, A, Mkpojiogu, EOC\& Hassan, F (2018), Dimensions and sub-dimensions for the evaluation of m-learning apps for children: A review. International Journal of Engineering \& Technology (IJET) 7 (3.20), 291-295. https://doi.org/10.14419/ijet.v7i3.20.19168

[30] Forsell, C \& Johansson, J (2010), An heuristic set for evaluation in information visualization. Proceedings of the International Conference on Advanced Visual Interfaces, ACM, pp: 199-206. https://doi.org/10.1145/1842993.1843029

[31] Krippendorff, K (2004), Content Analysis: An introduction to its methodology, (Sage Publications Inc., United States, 2004).

[32] Gehrke, D \& Turban, E (1999), Determinants of successful website design: Relative importance and recommendations for effectiveness, Proc. 32nd Hawaii Int. Conf. System Sciences. https://doi.org/10.1109/hicss.1999.772943

[33] Harrison, R, Flood, D \& Duce, D (2013), Usability of mobile applications: Literature Review and Rationale for A New Usability Model, 1-16. https://doi.org/10.1186/2194$\underline{0827-1-1}$

[34] Hussain, A \& Mkpojiogu, EOC (2015), An application of the ISO/IEC 25010 standard in the quality-in-use assessment of an online health awareness system, J. Teknol., 77(5) 9-13. https://doi.org/10.11113/jt.v77.6107

[35] El-Gayar, O, Timsina, P, Nawar, N, \& Eid, W (2013), Mobile applications for diabetes self-management: Status and potential, J. Diabetes Sci. Technol., 7(1), 247-262.

[36] Naismith, L (2004), Literature review in mobile technologies and learning, NESTA Futur. Ser. ; Rep. 11, p: 44. https://doi.org/10.1177/193229681300700130

[37] Hussain, A, Abd Razak, MNF, Mkpojiogu, EOC \& Hamdi, MMF (2017), UX evaluation of a video streaming application with teenage users. Journal of Telecommunication, Electronic \& Computer Engineering (JTEC), 9 (2-11), 129-131.

[38] Naslund, JA, Aschbrenner, KA, Marsch, LA \& Bartels, SJ (2016), The future of mental health care: Peer-To-peer support and social media, Epidemiol. Psychiatr. Sci., 25 (2), 113-122. https://doi.org/10.1017/s2045796015001067

[39] Hussain, A, Isam, M \& Mkpojiogu, EOC (2017), A UX assessment of a mobile recommender app for household electrical energy savings. Journal of Telecommunication, Electronic \& Computer Engineering (JTEC), 9 (2-11)

[40] Joo, S, Lin, S \& Lu, K (2011), A Usability Evaluation Model for Academic Library Websites: Efficiency, Effectiveness and Learnability, J. Libr. Inf. Stud., 9(2), 11-26. 
[41] Toribio-Guzmán, JM, García-Holgado, A, Pérez, FS, García-Peñalvo, FJ \& Martín, MAF (2016), Study of the Usability of the Private Social Network SocialNet using Heuristic Evaluation, Proc. XVII Int. Conf. Hum. Comput. Interact. - Interacción '16, pp: 1-5. https://doi.org/10.1145/2998626.2998674

[42] Hussain, A, Mkpojiogu, EOC \& Jasin, NMD (2017), Usability metrics and methods for public transportation applications: a systematic review. Journal of Engineering Science and Technology (JESTEC), Special Issue on ISSC'16, 4, 98-105.

[43] Chiang, KP \& Dholakia, RR (2003), Factors Driving Consumer Intention to Shop Online: An Empirical Investigation, Journal of Consumer psychology, 13(1\&2), 177-183. https:// doi.org/10.1207/s15327663jcp13-1\&2 16

[44] Hussain, A, Isam, M \& Mkpojiogu, EOC (2017), A UX assessment of a mobile recommender app for household electrical energy savings. Journal of Telecommunication, Electronic \& Computer Engineering (JTEC), 9 (2-11)

[45] Bangor, A, Kortum, P \& Miller, J (2009), Determining what individual SUS scores mean: Adding an adjective rating scale. Journal of Usability Studies, 4(3), 114-123.

[46] Hussain, A, Mkpojiogu, EOC, Musa, J \& Mortada, S (2017), A user experience evaluation of amazon kindle mobile application. Proceedings of the $2^{\text {nd }}$ International Conference on Applied Science and Technology (ICAST'17), Kedah, Malaysia. AIP Conference Proceedings 1891 (1), 020060, https://doi.org/10.1063/1.5005393

[47] Nielsen, J (1993), Usability Engineering, Academic Press, United States.

[48] Hussain, A, Mkpojiogu, EOC, Fadzil,NM \& Hassan, NM (2017), The UX of amila pregnancy on mobile device. Proceedings of the $2^{\text {nd }}$ International Conference on Applied Science and Technology (ICAST'17), Kedah, Malaysia. IP Conference Proceedings 1891 (1), 020061, https://doi.org/10.1063/1.5005394

[49] Kiseol, Y \& Hye-Young, K (2012), Mobile shopping motivation: an application of multiple discriminant analysis, International Journal of Retail \& Distribution Management, 40(10), 778-789. https://doi.org/10.1108/09590551211263182

[50] Hussain, A, Mkpojiogu, EOC, Abubakar,H \& Hassan, HM (2017), The usability evaluation of mudah.my on mobile device. Proceedings of the $2^{\text {nd }}$ International Conference on Applied Science and Technology (ICAST'17), Kedah, Malaysia. AIP Conference Proceedings 1891 (1), 020058; https://doi.org/10.1063/1.5005391

[51] Ferré, X, Juristo, N, Windl, H \& Constantine, L, Usability engineering Usability Basics, IEEE Softw., 18 https://doi.org/10.1109/52.903160

[52] Hussain, A, Mkpojiogu, EOC, Jamaludin, NH \& Moh, STL (2017), A usability evaluation of Lazada mobile application. Proceedings of the $2^{\text {nd }}$ International Conference on Applied Science and Technology (ICAST'17), Kedah, Malaysia. AIP Conference Proceedings 1891 (1), 020059, https://doi.org/10.1063/1.5005392

[53] Limayem, M, Khalifa, M \& Frini, A (2000), What make consumer buy from internet? A Longitudinal study of online shopping. IEEE Transactions on Systems, Man, and Cybernetics - Part A: Systems and Humans, 30(4). https://doi.org/10.1109/3468.852436

\section{Authors}

Azham Hussain is the Associate Professor of Software Engineering at School of Computing, Universiti Utara Malaysia, Kedah, Malaysia. He is the founder of Human-Centered Computing Research Group, which is affiliated with the Software Technology Research Platform Center at School of Computing, Universiti Utara Malaysia. Azham Hussain is a member of the US-based Institute of Electrical and 
Electronic Engineers (IEEE), and actively involved in both IEEE Communications and IEEE Computer societies.

Emmanuel O.C. Mkpojiogu is a Lecturer at Department of Computer and Information Technology, Veritas University, Abuja, Nigeria. Currently, he is a $\mathrm{PhD}$ student at School of Computing, Universiti Utara Malaysia. The research area is User Experience, Human Computer Interaction and Software Engineering. He has published many articles in reputable Scopus indexed journals. mkpojiogue@gmail.com

Noor Nabeel graduated from School of Computing, Universiti Utara Malaysia. His research area includes User Experience, Human Computer Interaction and Software Engineering.

Ahmed Al-Athwari is a former web developer at YemenSoft Company, Sana'a, Yemen. Currently, he is a master student at school of computing, Universiti Utara Malaysia. He is doing research on Software Engineering and IT Management.

Article submitted 2019-07-15. Resubmitted 2019-09-19. Final acceptance 2019-09-22. Final version published as submitted by the authors. 